\title{
EchoGéo
}

36 | 2016

Stratégies de villes et "modèles urbains"

\section{City strategies and urban " models »: an economic and geopolitical approach to inter-city relations}

Introduction

Elisabeth Peyroux and Thierry Sanjuan

\section{OpenEdition}

\section{Journals}

Electronic version

URL: https://journals.openedition.org/echogeo/14823

DOI: 10.4000/echogeo.14823

ISSN: 1963-1197

Publisher

Pôle de recherche pour l'organisation et la diffusion de l'information géographique (CNRS UMR 8586)

Electronic reference

Elisabeth Peyroux and Thierry Sanjuan, "City strategies and urban « models »: an economic and geopolitical approach to inter-city relations", EchoGéo [Online], 36 | 2016, Online since 30 June 2016, connection on 10 August 2021. URL: http://journals.openedition.org/echogeo/14823 ; DOI: https:// doi.org/10.4000/echogeo.14823

This text was automatically generated on 10 August 2021

EchoGéo est mis à disposition selon les termes de la licence Creative Commons Attribution - Pas d'Utilisation Commerciale - Pas de Modification 4.0 International (CC BY-NC-ND) 


\title{
City strategies and urban « models »: an economic and geopolitical approach to inter-city relations
}

\author{
Introduction \\ Elisabeth Peyroux and Thierry Sanjuan
}

1 This issue examines city strategies through the international circulation of « urban models ». This theme, which cuts across several disciplines, has been the object of renewed interest over the last few years, more specifically in French and Englishlanguage geography and urban studies. We include talks and discussions that were presented at the multi-disciplinary seminar «Circulation des références urbaines et assemblages locaux» [ "Circulation of urban references and local combinations»] which was organized from 2014 with the support of the Prodig research unit (UMR 8586) and Labex DynamiTe.

2 The notion of urban "model ", which we will draw upon throughout this issue, refers to a set of objects, policies, urban planning doctrines, "good practice» and benchmarks that share one character in common: they all refer to a standard to be imitated or replicated in a different context to that of its initial production. We chose to start from examples of cities which are already considered as models of « good practice ", in order to define, working both from theory and from diverse and specific cases, what is meant by the word «model ». As specified in Herman van der Wusten's article, we have not included models that referred to a theoretical description to explain certain aspects of a city's morphology and functioning, but rather models that highlighted some essential features of a city in the making. Those include spatial projections and images of the future city (Choay, 1965) (such as the "smart city" described by Languillon) as well as sector-specific models - urban management, governance - with a strong social and normative dimension (looking at the example of Johannesburg, a city that aspires to be "resilient ", « inclusive " and "sustainable », 
through justice and equal opportunities) ; the application of concepts to public policies ( the "creative city" policy in Saint-Etienne); the aspiration to new urban development models (the "sustainable city» as illustrated by the examples of Northern European cities and Amman); or alternative practices developed as part of a set of «tactical», "sustainable and collaborative » urban planning practices (Douay and Prévot).

3 Our approach to the notion of "urban models" embraces both the intellectual (through standards and values) and material aspects of cities, looking into urban forms and architectural objects as well as administration and governance models. This issue feeds into current debates on the international circulation of urban models and policies, while contributing complementary approaches and an original perspective. The chosen angle is to look at these models from an instrumental perspective : the strategies of cities and their international positioning, as seen through the production, transfer, circulation and reception of « urban models » - all the while challenging and deconstructing this notion, and showing its instrumentalisation for the purposes of economic and geopolitical power play. This might lead us to reconsider hierarchies between cities, as small or medium-sized cities can be just as influent as metropolises in terms of innovation and creativity.

4 In the last few years, a lot of French and English-language studies have interrogated the increasingly fast and intense international circulation of urban policies. A new field recently emerged around « urban policy mobility ", raising a number of questions: how do policies become mobile and mutate? How are they appropriated, adopted, translated, modified and relocated in a new environment? What resources and channels of circulation are used by stakeholders to produce, disseminate and territorialise policy-related knowledge (Peck et Theodore, 2010; McCann, 2011; McCann et Ward, 2010, 2011, 2012; Temenos et McCann, 2013; Baker et Temenos, 2015) ? For instance, in South-East Asia, the circulation of urban models is referred to as "project-based urban planning»: large cities have undergone a moderate metropolisation process (Franck et al., 2012), borrowing from regional models without inventing a specific regional or universal model of Asian cities (Franck and Sanjuan, 2015).

5 These questions reactivate a familiar topic: the forms assumed by the historic production of the city, including the appropriation of foreign models, and the dissemination of urban and architectural models (Harris et Moore, 2013). These topics have however undergone a theoretical and methodological update, due to the critique of traditional approaches in political science (policy transfer) and to the last few years' major theoretical breakthroughs: the " turn of mobility » in sociology (Urry, 2007) and more broadly social science (Söderström et al., 2013a), the emergence of an open and relational conception of space in geography and urban studies (Massey 1991, Jacobs, 2012), and the rise of « urban cosmopolitanism » with its interest in the experiences of very diverse cities, both in the North and the South, in line with post-colonial approaches (Robinson, 2006, 2011a; McFarlane et Robinson, 2012; Parnell et Robinson, 2012).

6 Although they draw upon other theoretical and conceptual approaches to address the policies' trajectories and local adaptation, English and French language scholarship have in common their challenging of the notions of export and transfer, based on the complexity of circulation and local appropriation processes, and on the multi- 
directional trajectories of these «models" (Moussi, 2010; Peck and Theodore, 2010; Södertröm and Paquot, 2012).

7 Scholars investigate the tensions at the heart of the ways these policies and models circulate and become settled; they focus on the selective character of circulation processes, and on the role of the reception context ; they analyse the new territorial and relational geographies that take shape between cities (McCann et Ward, 2010; Robinson, 2011b; Söderström et al., 2013b; Söderström, 2014). They consider the diversity of stakeholders involved in the circulation of models, highlighting the role played by the designers' professional practices and skills (Moussi, 2010; Cook et al., 2014), by property developers (Morange et al., 2009, 2012), by the trajectories of individuals and firms (Verdeil, 2005), by consultants (Prince, 2012), and by the cities' epistemic communities and international networks (Peyroux 2012; Clarke, 2011). They highlight the role played by the circulation of policies and models in the consolidation and reproduction of dominant doctrines and ideologies, and in some cases the resistence they encounter (Peck et Théodore, 2010; Didier et al., 2009, 2012, 2013; BénitGbaffou et al., 2012). Finally, they challenge traditional representations according to which innovation hubs are necessarily located in the countries of the North (Moussi, 2010), highlighting the emergence of new hubs of expertise in the South (Verdeil, 2005) and the role played by South/South relations in the production and dissemination of innovative models (Wood, 2015).

8 Contributions to this issue show that due to the diverse range of contexts, stakeholders and models, as well as to the diversity of circulation channels, it is necessary to take into account their frames of reference and values, not just as elements of background (whose role is now undermined by globalisation) but as decisive factors that are forcefully re-emerging under the influence of historical, national, political and cultural factors. Eastern European nationalism, religious radicalisation in some Muslim states and the accelerated modernisation of economically emergent countries - along with the presence of international bodies and multinationals - are influencing the take up of these "urban models", creating phenomena of resistance, appropriation or local replication. In this respect, it has been essential for the articles compiled in this issue to analyse the interplay of public and private stakeholders on diverse scales, to both study the international trajectories of policies and models, and understand the way in which those are assembled locally under the influence of international templates.

9 Our idea was to focus first and foremost on the influences and power struggles that affect the production and circulation of urban models. We looked at the strategies designed, implemented and in some cases endured by local or metropolitan authorities and other stakeholders (private players, investors, developers, architects, experts) in diverse fields (planning, development, management, business) and on various scales (district, city, state, region, continent).

10 Economic competition, together with the introduction of a sense of competition between cities by the media and international bodies (through benchmarks of cities or the identification of " good practice »), obviously play a crucial part in urban strategies. Some of these strategies are formed under international pressure and motivated by communication purposes, in the absence of any initial impetus from public authorities. Relations between cities are also formed within a changing geopolitical context, whose stakes and implications need to be understood. Our use of the term "geopolitical» implies a pacified understanding of geopolitical relations: it does not refer to any actual 
conflict, or to competition for sovereignty on a national or local territory, but to relations of competition between cities based on rivalries in terms of international positioning within a geopolitical frame of reference. The term «strategy " itself is not neutral : this military expression, which refers to the implementation of a medium and long-term plan, intentionally suggests a process of structural conquest (in this case, regarding networks, institutions and fluxes). This geopolitical dimension needs to be placed within the context of the economic and diplomatic rise of Southern countries and cities, in particular emergent ones. It highlights the part played, now as ever, by state authorities in the circulation and adoption of models (Béal et al., 2015 ; see also in this issue Peyroux and Languillon's articles), even though these entities do not follow the same political timelines as cities.

11 Finally, we explored the question of how and to which extent the production, appropriation and circulation of urban models has contributed to creating or updating the categories and functions of cities, and to forming new bonds between them (see Peyroux' article in this issue).

In his eminently typological article, Herman van der Wusten presents the main « urban models » that appeared in succession after Le Corbusier's functional city, evaluating their approaches, contributions, evolutions and outcomes. According to his analysis, there is not anymore a globally available universal model, and the various models are instead combined to create forms such as Giovanni Sechi's creative city.

Camille Girauld questions the model of sustainable cities, through the example of Northern European cities. His paper shows the ambitions and performances that have fuelled the construction of the environment-centric Northern model with its urban variants, and how this model is today being instrumentalised by cities to gain leverage on a European and global scale, in the current context of competition between metropolises. The model of the sustainable city also responds to geopolitical stakes to do with supply and demand in energy : cities are in need of autonomy in terms of decision-making and action. The analysis stresses that there is no such thing as a sustainable Northern city model per se: this model needs to be validated through its construction and circulation. It is formed in stages on the various scales of the territory, with secondary cities acting as examples. The paper highlights the diversity of stakeholders involved in the production and circulation of this model : the European Union through the attribution of its label, the cities through their participatory governance practices, innovation and communication capacities and urban marketing, or the private sector (businesses, consultancy firms, think tanks).

Elliot Ducharm studies the implementation over the last ten years in Amman of transport and mobility policies under the claim of sustainable development principles. He analyses how Southern cities are affected by globalisation and neoliberalisation, looking at the active and strategic role played by the Amman city authorities. The city is seeking to assert itself within the national territory and stand out from the region's other cities by articulating an international vision - taking part in networks of cities with a local one: the notion of the "sustainable city " summons up territorial issues such as devolution and democratisation, as well as power struggles. The notion becomes a means of emancipation for the capital, in the context of a bureaucratic and centralised state where the population develops increasingly standardised urban practices. 

model » with their study of tactical urbanism - a practice that allows citizens to take material action to improve their immediate everyday urban environment, without waiting for urban planning authorities/stakeholders to respond to their aspirations. The case of Paris, studied through the examples of Paris Plage and the « Parking Days ", illustrates the reception of this model and its relatively fast institutionalisation in a context where the circulation and adaptation of initiatives depends on the key role played by social networks.

19 Altogether, this issue is an opportunity to highlight the increased complexity of the production and circulation of « urban models » due to the instrumentalisation of these models by urban strategies, in the context of new relations with the central state where influence and power operate on diverse scales. These questions also point to a reconfiguration of relations between Northern and Southern cities, and between Southern cities themselves. We conclude on a twofold contemporary trend: the increasing power of cities - with their private and public partners -, against the original influence of the state; and the recomposition of the very notion of «model » due to strategies of influence that either take inspiration from specific experiences or borrow 
parts of those without imitating or replicating them. This issue of EchoGéo is an invitation to reconsider the political role played by cities on the international stage, in the context of a consolidation of transnational networks of cities, giving rise to new governance practices and new modes for the production, dissemination and circulation of urban standards and policies.

\section{BIBLIOGRAPHY}

Baker T., Temenos C., 2015. Urban policy mobilities research: Introduction to a debate. International Journal of Urban and Regional Research, 39, p. 824-827.

Béal V., Epstein R., Pinson G., 2015. La circulation croisée. Modèles, labels et bonnes pratiques dans les rapports centre-périphérie. Gouvernement et action publique, 3, p. 103-127.

Bénit-Gbaffou C., Didier S., Peyroux E., 2012. Circulation of security models in Southern African cities: Between neoliberal encroachment and local power dynamics. The International Journal of Urban and Regional Research, numéro special, 36 (5), p. 877-889.

Choay F., 1965. L'Urbanisme, utopie et réalité. Paris, Seuil.

Clarke N., 2011. Urban policy mobility, anti-politics, and histories of the transnational municipal movement. Progress in Human Geography, 35 (4), p. 1-19.

Cook I. R., Ward S. V., Ward K. (2014) A springtime journey to the Soviet Union: Postwar planning and policy mobilities through the Iron Curtain. International Journal of Urban and Regional Research, 38 , p. 805-822.

Didier S., Morange M., Peyroux E., 2013. The adaptive nature of neoliberalism at the local scale: Fifteen years of City Improvement Districts in Cape Town and Johannesburg. Antipode, 45 (1), p. 121-139.

Didier S., Peyroux E., Morange M. (2012) The spreading of the City Improvement District model in Johannesburg and Cape Town: Urban regeneration and the neoliberal agenda in South Africa. The International Journal of Urban and Regional Research, 36 (5), p. 915-935.

Didier S., Peyroux E., Morange M., 2009. La diffusion de la formule des City Improvement Districts (CIDs) à Johannesburg et au Cap : régénération urbaine et agenda néolibéral en Afrique du Sud. In Bénit-Gbaffou C., Fabiyi S., Peyroux E. (dir.), Sécurisation des quartiers et gouvernance locale. Enjeux et défis pour les villes africaines (Afrique du Sud, Kenya, Mozambique, Namibie, Nigéria). Paris, IFASKarthala, p. 85-112.

Franck M., Goldblum C., Taillard C. (dir.), 2012. Territoires de l'urbain en Asie du Sud-Est : métropolisations en mode mineur. Paris, CNRS Éditions.

Franck M., Sanjuan T. (dir.), 2015. Territoires de l'urbain en Asie. Une nouvelle modernité ? Paris, CNRS Éditions.

Harris A. J., Moore S. M., 2013. Planning histories and practices of circulating urban knowledge. International Journal of Urban and Regional Research, 37 (5), p. 1499-1509. 
Jacobs, J. M., 2012. Urban geographies I: Still thinking cities relationally. Progress in Human Geography, 36(3), p. 412-422.

Massey, D., 1991. A global sense of place. Marxism Today, (38), p. 24-29.

Moussi M., 2010. Trajectoires et transactions de modèles urbains. Échafaudages théoriques et accommodements locaux. Les Cahiers d'EMAM, 20, p. 9-22.

McCann E., Ward K., 2010. Relationality/territoriality: toward a conceptualization of cities in the world. Geoforum, 41, p. 175-184.

McCann E., 2011. Urban policy mobilities and global circuits of knowledge. Towards a research agenda/ Annals of the Association of American Geographers, 101(1), p. 107-130.

McCann E., Ward K., 2011. Mobile Urbanism: City Policymaking in the Global Age. Minnesota, University of Minnesota Press.

McCann E., Ward K., 2012. Assembling urbanism: Following policies and 'studying through' the sites and situations of policy making. Environment and Planning A, 44, p. 42 -51.

McFarlane C., Robinson, J., 2012. Introduction: Experiments in comparative urbanism. Urban Geography, 33 (2), p. 765-773.

Morange M., Folio F., Peyroux E., Vivet J., 2009. Déclinaisons locales d'un modèle international : les « gated communities » à la conquête de l'Afrique australe. In Bénit-Gbaffou C., Fabiyi O., Peyroux E. (dir.), Sécurisation des quartiers et gouvernance locale. Enjeux et défis pour les villes africaines (Afrique du Sud, Kenya, Mozambique, Namibie, Nigeria). Paris, IFAS-Karthala, p. 47-83.

Morange M., Folio F., Peyroux E., Vivet J., 2012. The spread of a transnational model: "gated communities" in three Southern African cities (Cape Town, Maputo and Windhoek). The International Journal of Urban and Regional Research, 36(5), p. 890-914.

Parnell, S., Robinson J., 2012. (Re)theorizing cities from the Global South: Looking beyond neoliberalism. Urban Geography, 33(4), p. 593-617.

Peck J., Theodore N., 2010. Mobilizing policy: Models, methods, and mutations. Geoforum, 41, p. 169-174.

Peyroux E., 2012. Circulation internationale et construction sociale d'un « modèle » de gestion des services urbains : les City Improvement Districts à Johannesburg. L'Espace Géographique, $\mathrm{n}^{\circ}$ spécial « Réseaux et équipements dans les villes africaines », 41,1/12, p. 68-81.

Prince R., 2012. Policy transfer, consultants and the geographies of governance. Progress in Human Geography, 36 (2), p. 188-203.

Robinson J., 2006. Ordinary Cities: Between Modernity and Development. Abingdon, Routledge.

Robinson, J., 2011a. Cities in a world of cities: The comparative gesture. International Journal of Urban and Regional Research, 35(1), p. 1-23.

Robinson, J., 2011b. The spaces of circulating knowledge: City strategies and global urban governmentality. In McCann, E., Ward K., (dir.), Mobile Urbanism. University of Minnesota Press, p. 15-39.

Söderström O., Paquot T., 2012. Modèles urbains. Editorial du dossier spécial. Urbanisme, 383, mars-avril, p. 43-45.

Söderström O., 2014. Cities in Relation. Trajectories of Urban Development in Hanoi and Ouagadougou. Oxford, Wiley-Blackwell. 
Söderström O., Dupuis B., Leu P., 2013a. Translocal urbanism: How Ouagadougou strategically uses decentralised cooperation. In Obrist B. et al., Living the African City. Basel, SGAS (with Lit Verlag), p. 99-118.

Söderström O., D’Amato G., Ruedin D., Panese F., Randeria S., 2013. Critical Mobilities. London, Routledge.

Temenos C., McCann E., 2013. Geographies of policy mobilities. Geography Compass, 7, p. 344-357.

Urry J., 2007. Mobilities. Cambridge, Polity Press.

Verdeil E., 2005. Expertises nomades au Sud. Éclairages sur la circulation des modèles urbains. Géocarrefour, 80 (3), p. 165-169.

Wood A., 2015. The politics of policy circulation: Unpacking the relationship between South African and South American cities in the adoption of Bus Rapid Transit. Antipode, 47, p. 1062-1079.

\section{INDEX}

Subjects: Sur le Champ - Sur le Terrain

\section{AUTHORS}

\section{ELISABETH PEYROUX}

Elisabeth Peyroux, elisabeth.peyroux@cnrs.fr, is a Research Fellow at the Centre National de la Recherche Scientifique (CNRS) and a member of the Prodig research unit (UMR). Her recent publications include:

- Peyroux E., 2015. Discourse of Urban Resilience and 'Inclusive Development' in the Johannesburg Growth and Development Strategy 2040. European Journal of Development Research, 27 (4), p. 560-573.

- Peyroux E., 2014. Social entrepreneurship and corporate social responsibility in Johannesburg's inner city housing and revitalisation strategies. In Haferburg, C. and Huchzermeyer, M. (dirs.), Urban Governance in Post-Apartheid Cities: Modes of Engagement in South Africa's Metropoles. Borntraeger Science Publishers, Stuttgart, p. 231-250.

- Bénit-Gbaffou C., Didier S., Peyroux E., 2012. Circulation of security models in Southern African cities : Between neoliberal encroachment and local power dynamics. The International Journal of Urban and Regional Research, 36 (5), p. 877-889.

\section{THIERRY SANJUAN}

Thierry Sanjuan, Thierry.Sanjuan@univ-paris1.fr, is a University Professor at Université Paris 1 Panthéon Sorbonne and a member of the Prodig research unit (UMR). His recent publications include:

- Sanjuan T., 2015. Atlas de la Chine. Une puissance sous tension. Paris, Autrement, 3e édition, 96 p. - Franck M., Sanjuan T., 2015. Territoires de l'urbain en Asie. Une nouvelle modernité ? Paris, CNRS Éditions, 402 p. 